\title{
Anatomic Variations of Extrahepatic Bile Ducts and Evaluation of the Length of Ducts Composing the Cystohepatic Triangle
}

\author{
Variaciones Anatómicas de los Ductos Biliares Extrahepáticos \\ y Longitud de los Ductos del Trígono Hepato-cístico
}

"Eduardo Cachoeira;"Antonio Rivas \& ** Carla Gabrielli

CACHOEIRA, E.; RIVAS, A. \& GABRIELLI, C. Anatomic variations of extrahepatic bile ducts and evaluation of the length of ducts composing the cystohepatic triangle. Int. J. Morphol., 30(1):279-283, 2012.

SUMMARY: It is of paramount importance for surgeons to have a thorough knowledge of the normal anatomy of the extrahepatic bile ducts and its variations due to the high frequency with which they perform in this anatomic site. The cystohepatic triangle, or Calot's Triangle, is bound by the cystic duct, common hepatic duct, and the hepatic border; therefore, its surface area depends on the conformation of these ducts and is closely linked to surgical procedures performed in this region. It has been reported that the length and the position of these ducts may be related to the formation of bile duct stones, Mirizzi's syndrome, and bile duct cancer. Thus, the present work aims to analyze the configuration of the extrahepatic biliary tree and its possible variations, as well as measure the components that make up the cystohepatic triangle. For this task 41 samples from fixated human cadavers were analyzed, with 25 consisting of anatomic parts (liver and biliary tree) and 16 in situ samples. The extrahepatic biliary trees were dissected in order to measure the length of the common hepatic and cystic ducts with a digital caliper, and all anatomic variations were registered. The length of the common hepatic duct varied between $4.18 \mathrm{~mm}$ and $50.64 \mathrm{~mm}$, with an average of $21.76 \pm 9.51 \mathrm{~mm}$. The length of the cystic duct varied between 7.28 and $38.88 \mathrm{~mm}$, with an average of $19.11 \pm 6.77 \mathrm{~mm}$. Anatomic variations were found in 3 samples $(7.3 \%)$ : in one of them the cystic duct connected to the left hepatic duct; in another, the cystic duct connected to the right hepatic duct; in the third, there was a triple confluence of hepatic ducts (two right ducts and one left duct). The results are a contribution to the clinical and surgical anatomy of this region.

KEY WORDS: Anatomy; Cystohepatic triangle, Common hepatic duct; Cystic duct; Cholecystectomy.

\section{INTRODUCTION}

Extrahepatic bile ducts constitute a greatly important anatomic site for medical practice where surgeons frequently perform. It is indispensible for the surgeon to know thoroughly the anatomy of this region, as well as its morphologic and topographic variations in order to avoid complications during the operation.

The length of the common hepatic and cystic ducts, as well as the existence of anatomic variations in the biliary tree are closely related to the existence, extension of the surface area, and position of the cystohepatic triangle (Calot's Triangle). The importance of this anatomical landmark is indisputable for performing the cholecystectomy - a common surgical procedure, which consists of the ligature of the cystic artery and the cystic duct for the subsequent removal of the gallbladder. Considering that in $56 \%$ of cases the cystic artery is bound by the cystohepatictriangle (Cavalcanti et al., 2002), this triangle is the key reference for the cholecystectomy procedure since its proper identification makes it much easier to expose and distinguish between the main structures involved in the resection of the gallbladder. That is particularly relevant when appreciating the severity of complications such as hemorrhage, leakage of bile into the peritoneal cavity, and portal vein thrombosis, associated with poor execution of the procedure (Cavalcanti et al.).

The normal extrahepatic biliary tract is formed by the right and left hepatic ducts (responsible for draining their respective lobes), which join together to form the common hepatic duct, which, in turn, drains the cystic duct from its lateral position. This configuration of the biliary tree is present in around 60\% of the population (Dohke et al., 1999; Mortelem \& Ros, 2001).

Variations in the hepatic ducts include the presence of accessory ducts, notable for communicating hepatic

\footnotetext{
* Curso de graduação em Medicina, Centro de Ciências da Saúde, Universidade Federal de Santa Catarina, Florianópolis, Santa Catarina, Brasil.

** Departamento de Ciências Morfológicas, Centro de Ciências Biológicas, Universidade Federal de Santa Catarina, Florianópolis, Santa Catarina, Brasil.
} 
segments with the extrahepatic biliary tract. Aberrant ducts which communicate the right hepatic lobe directly with the gallbladder have also been described (Foster \& Wayson, 1962; Lamah et al., 2001; Cavalcanti et al.) The cystic duct has three common variations: a) insertion into the distal third of the common hepatic duct (9\%); b) medial insertion through the left side of the common hepatic duct (10-17\%); c) course parallel to the common hepatic duct extending for $2 \mathrm{~cm}$ or more (1.5\%-25\%) according to Turner \& Fulcher (2001). On the other hand, insertion of the cystic duct into the left or right hepatic ducts, or influence of the left posterior hepatic duct directly into the cystic duct are considered rare (Turner \& Fulcher; Yamakawa et al., 2007).

Regarding duct length, besides influencing the surface area of the cystohepatic triangle, long ducts as well as a low insertion of the cystic duct would also be associated with a predisposition to stone formation, Mirizzi's Syndrome, and pancreatitis (Bornman et al., 1988; Uetsuji et al., 1993; Caroli-Bosc et al., 1997).

The aim of this work is to study the morphology of the extrahepatic biliary tract, analyzing its configuration and measuring the components which limit the cystohepatic triangle.

\section{MATERIAL AND METHOD}

A total of 41 samples from adult Brazilian individuals of both sexes, white and non-white, were analyzed after fixation with formaldehyde $10 \%$. Out of all 41 samples, 25 were anatomic parts consisting of dissected liver and biliary tract while 16 were in situ samples. The extrahepatic biliary tracts were dissected, and the length of the cystic and common hepatic ducts was measured with a digital caliper. Possible anatomic variations in the aforementioned tracts were also analyzed. Each sample was photographed and diagrams were made for each.

\section{RESULTS}

The length of the common hepatic duct varied between 4.18 and $50.64 \mathrm{~mm}$ with a mean average of 21.76 $\pm 9.51 \mathrm{~mm}$. These data were obtained from the length of the hepatic duct of 39 samples, since 2 did not present this duct, having instead a direct communication between the cystic duct and the left or right hepatic ducts. Figure 1 shows the distribution of range lengths for the common hepatic duct.

The length of the cystic duct varied between 7.28 and $38.88 \mathrm{~mm}$, with a mean average of $19.11 \pm 6.77 \mathrm{~mm}$. The distribution of samples within length ranges for the cystic duct is presented in Figure 2.

Anatomic variations were found in 3 of the 41 samples (7.31\%). In the first case, the cystic duct joined the right hepatic duct (Figs. 3a and 3b).

In the second case, the cystic duct passed posteriorly to the right hepatic duct and joined the left hepatic duct (Figs. 4a and 4b).

In the third case, the common hepatic duct was formed by the three hepatic ducts: the left hepatic duct and the anterior and posterior right hepatic ducts (Figs. 5a and 5b).

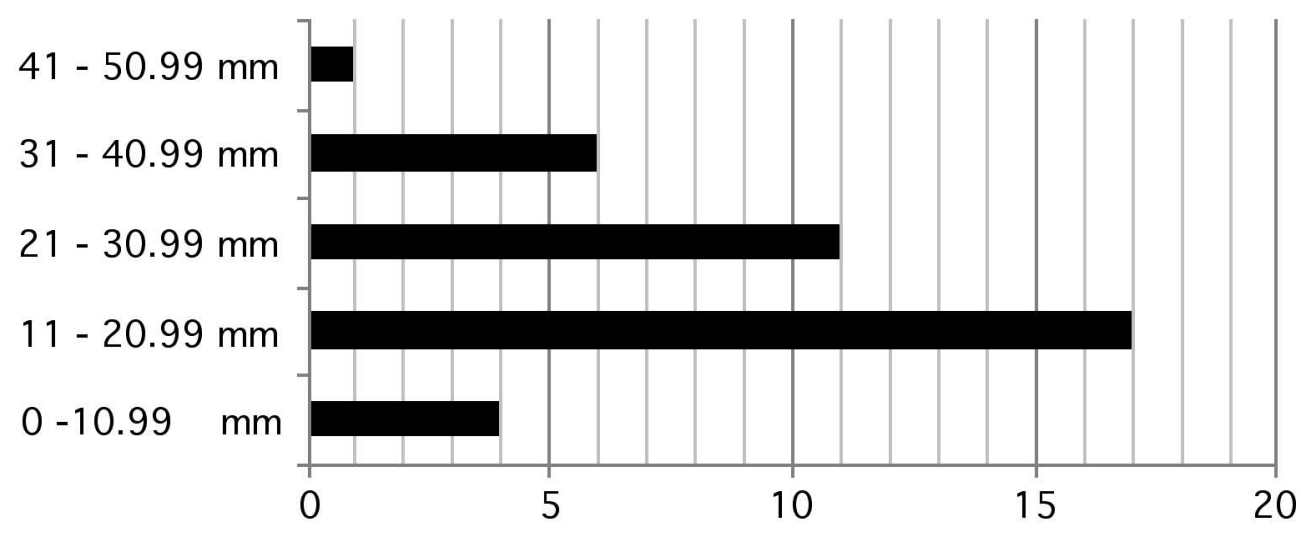

Fig. 1. Arrangement of samples by common hepatic duct length ranges. 


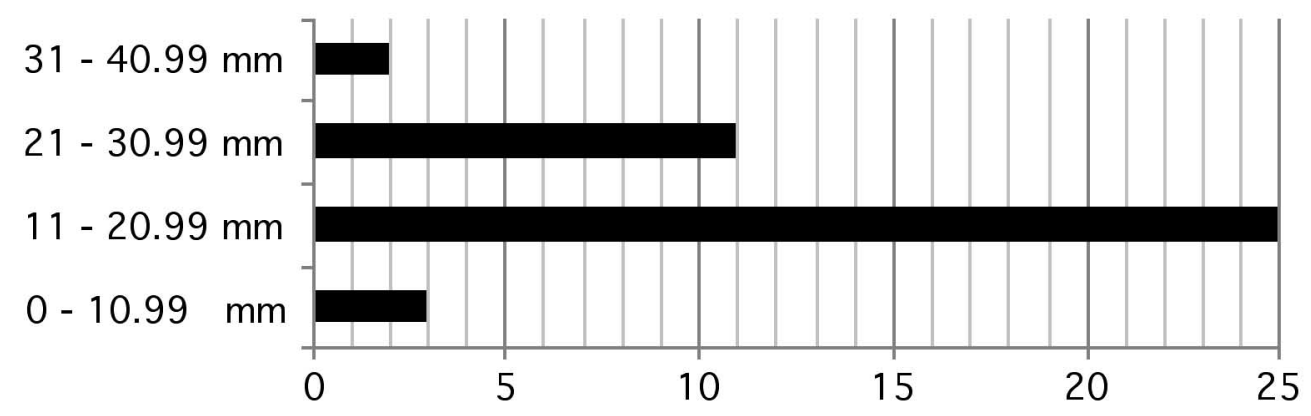

Fig. 2. Arrangement of samples by cystic duct length ranges.

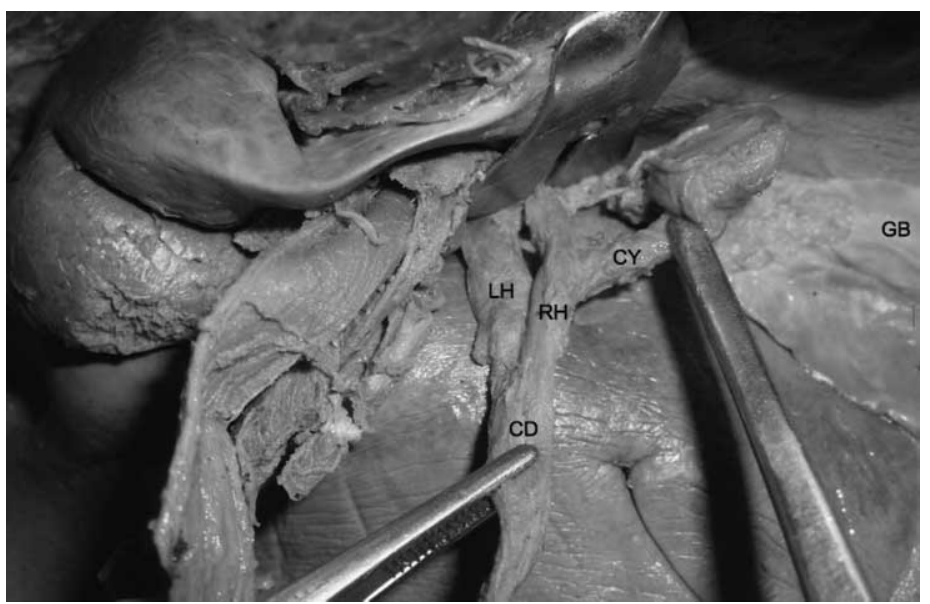

Fig. 3a. Visceral surface of the liver. The cystic duct (CY) joins the right hepatic duct (RH). LH - left hepatic duct; CD - choledoch duct; GB gallbladder.

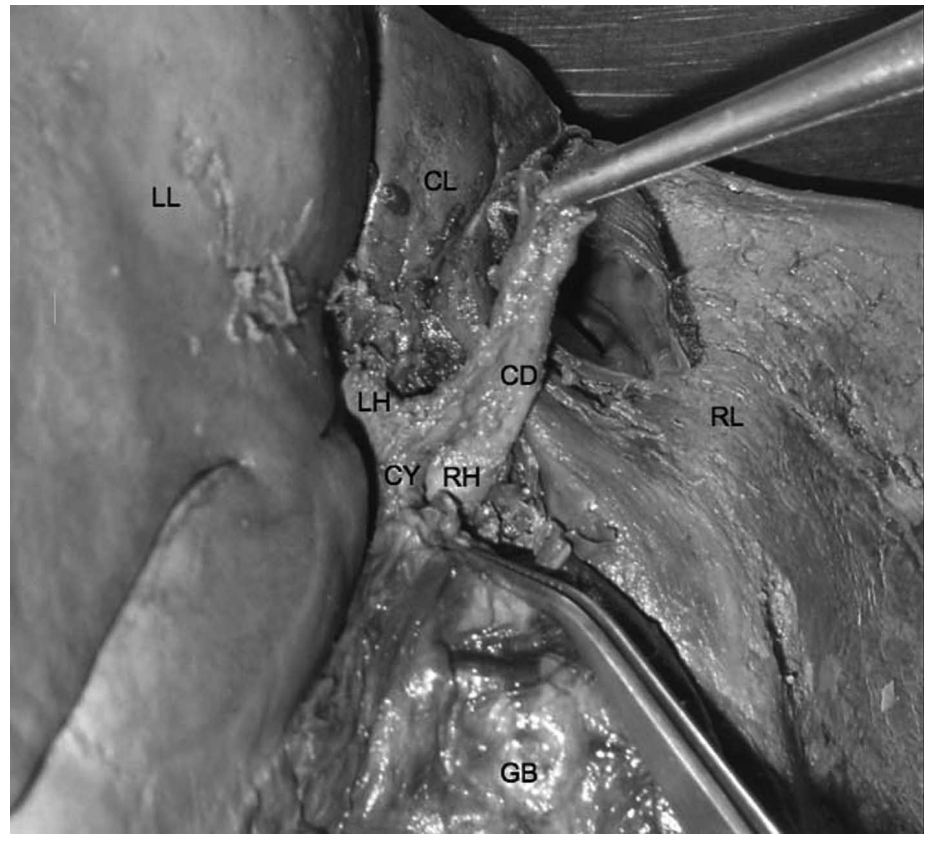

Fig. 4a. Cystic duct (CY) posteriorly crossing the right hepatic duct (RH) and joining the left hepatic duct (LH) through the visceral surface of the liver, with the choledoch duct (CD) superiorly displaced. LL - left hepatic lobe; RL - right hepatic lobe; $\mathrm{CL}$ - caudate lobe of the liver; GB - gallbladder.

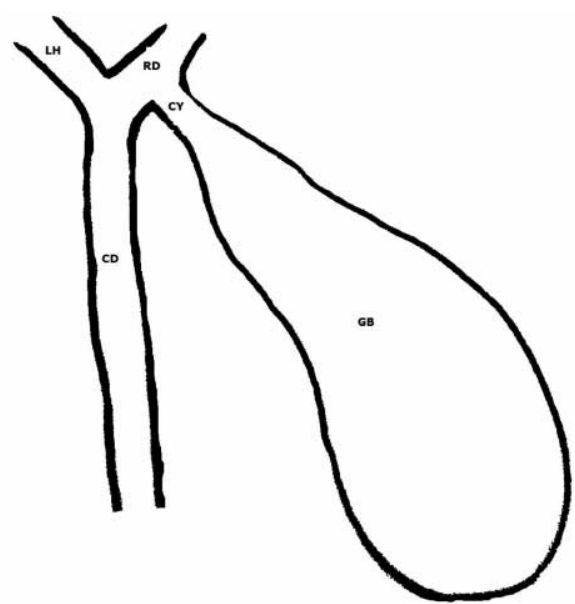

Fig. 3b. Schematic drawing of Figure 3a. CY - cystic duct; $\mathrm{RH}$ - right hepatic duct; $\mathrm{LH}$ - left hepatic duct; $\mathrm{CD}$ - choledoch duct; GB - gallbladder.

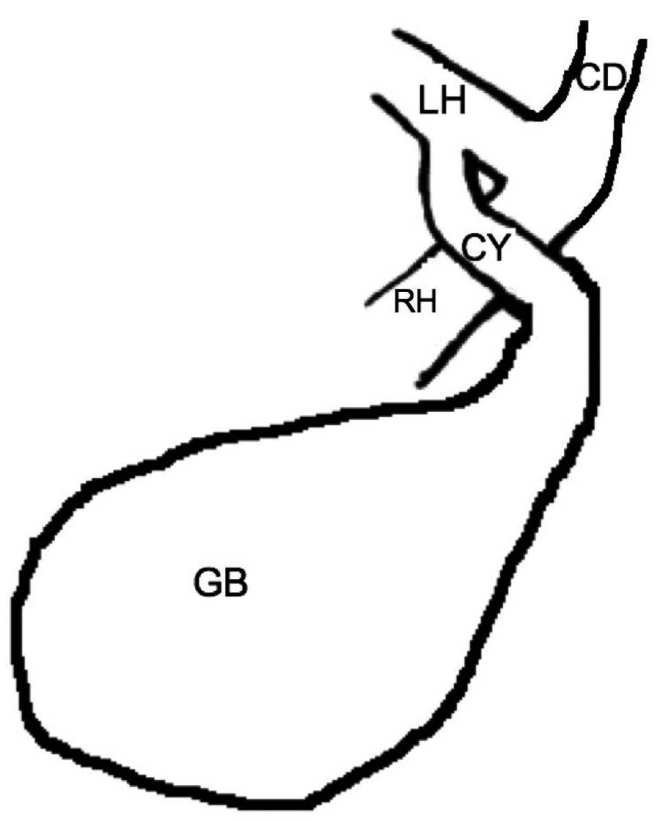

Fig. 4b. Schematic drawing of Figure 4a. CY - cystic duct; $\mathrm{RH}$ - right hepatic duct; $\mathrm{LH}$ - left hepatic duct; CD - choledoch duct; GB - gallbladder. 


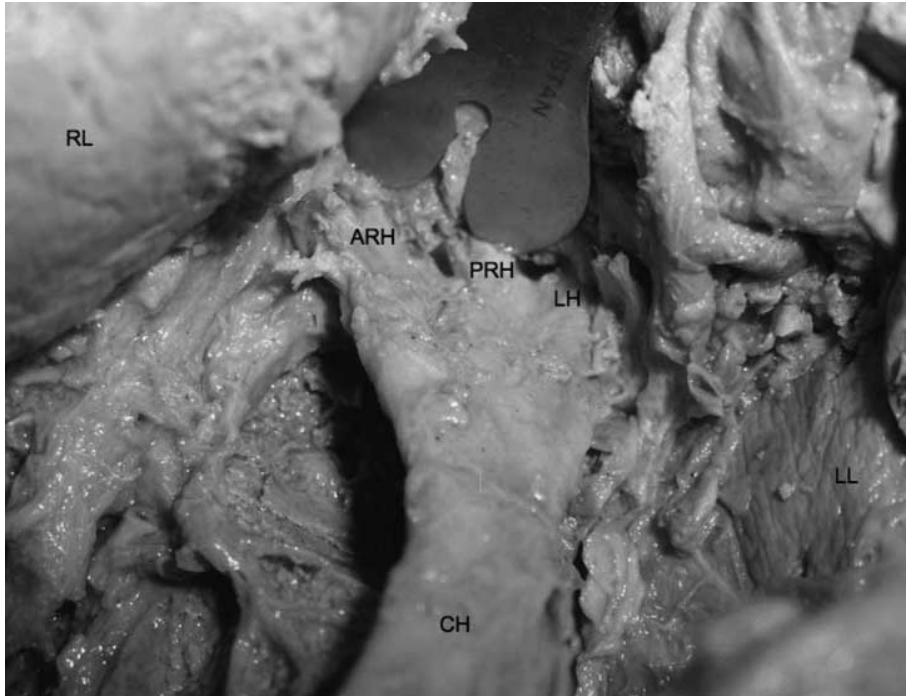

Fig. 5a. Triple confluence formation of the common hepatic duct $(\mathrm{CH})$. $\mathrm{ARH}$ - anterior right hepatic duct; $\mathrm{PRH}$ - posterior right hepatic duct; $\mathrm{LH}$ - left hepatic duct. LL - left hepatic lobe; RL - right hepatic lobe.

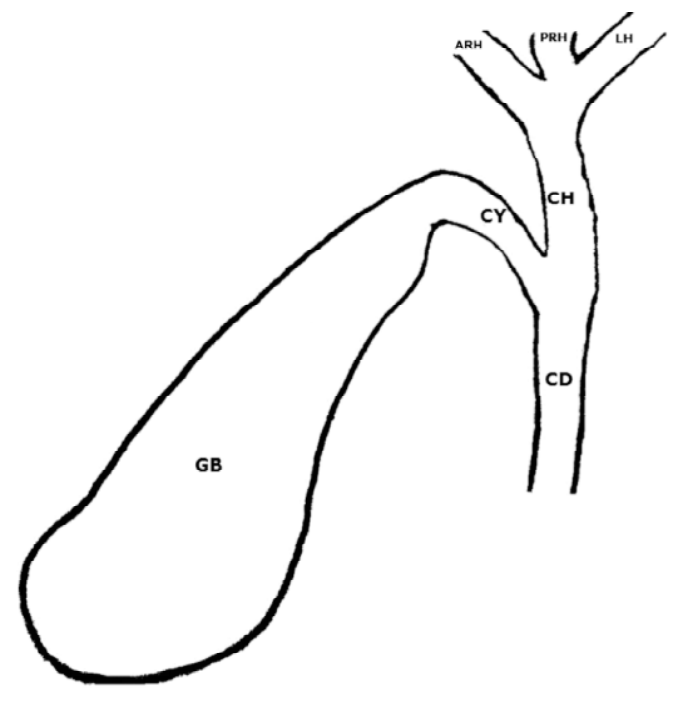

Fig. 5b. Schematic drawing of figure 5a. $\mathrm{CH}-$ common hepatic duct; ARH - anterior right hepatic duct; $\mathrm{PRH}-$ posterior right hepatic duct; $\mathrm{LH}$ - left hepatic duct; CY cystic duct; CD - choledoch duct; GB - gallbladder.

\section{DISCUSSION}

Three variations of the hepatocystic junction were observed in our samples, two of which are considered rare (Turner \& Fulcher; Yamakawa et al.). The first variation is represented by the cystic duct joining the right hepatic duct, with an estimated incidence ranging from 0.6 to $2.3 \%$ in the general population (Berci, 1992; Kwon et al., 1997). According to some authors, this variation presents an intrinsic surgical risk to a cholecystectomy, as the right hepatic duct may be confused with the cystic duct and so cut and ligated, producing a potentially dangerous outcome (Lahma et al.). The second variation had the cystic duct joining the left hepatic duct. It is an extremely rare anatomic variation, especially if the gallbladder sits in its normal position (Brandt \& Eckhauser, 1994; Fujita et al., 1996; Yamakawa et al.). Though less common, an intraoperative lesion is more likely to occur in this scenario, especially with a laparoscopic approach (Lahma et al.). As to the formation of the common hepatic duct, a variation called the triple confluence may be observed at the hepatic hilum. It is a relatively common variation and corresponds to the confluence of the right anterior and posterior bile ducts and the left bile duct forming the common hepatic duct, present in approximately $11 \%$ of the general population (Taourel et al., 1996; Dohke et al.; Mortelem et al.).

In our findings, the cystic duct measured between 0.7 and $3.9 \mathrm{~cm}$ in length, with an average of $1.9 \mathrm{~cm}$, slightly below the average found by other authors, which was around 2 to $4 \mathrm{~cm}$ (Turner \& Fulcher). According to Caroli-Bosc et al., there is an association between the size of the cystic duct and its left lateral attachment to the gallbladder, so that most laterally attached ducts had more than $3 \mathrm{~cm}$ in length, whereas the left attachment of the cystic duct would be associated with a greater incidence of bile stones.

The length of the common hepatic duct varied between 0.4 and $5.6 \mathrm{~cm}$, with a mean average of $2.17 \mathrm{~cm}$. No reference was found in the literature regarding this length.

No accessory bile ducts were found in the present study, which are described in the literature as having an incidence ranging from 1 to 30\% (Benson \& Page, 1976; Gibney et al., 1987).

A detailed knowledge of the extrahepatic biliary tract, as well as of its variations, is paramount for the diagnostic and therapeutic success in many clinical scenarios since they allow the surgeon prompt recognition of certain pathologies, making surgical approaches more precise and affective.

CACHOEIRA, E.; RIVAS, A. \& GABRIELLI, C. Variaciones anatómicas de los ductos biliares extrahepáticos y longitud de los ductos del trígono hepato-cístico. Int. J. Morphol., 30(1):279-283, 2012.

RESUMEN: El conocimiento de la anatomía normal de las vías biliares extrahepáticas y sus variaciones es fundamental para los cirujanos digestivos debido a la frecuencia con que se 
actúa en esa región. El trígono hepato-cístico o de Calot es delimitado por el ducto cístico, ducto hepático común y el margen del hígado. De este modo, su área depende de la conformación de esos ductos y está íntimamente relacionada a procedimientos quirúrgicos efectuados en esa zona. Se ha señalado que la longitud y la disposición de esos ductos estarían involucradas en la formación de cálculos biliares, síndrome de Mirizzi y neoplasias de vías biliares. Así, el presente estudio tuvo como objetivo analizar la configuración de las vías biliares extrahepáticas y sus posibles variaciones, además de registrar parámetros métricos de los componentes del sistema biliar que integran el trígono hepato-cístico. Para el estudio se utilizaron 41 muestras de cadáveres formolizados de individuos adultos, siendo 25 piezas anatómicas (de hígado y vías biliares) y 16 in situ. Las vías biliares fueron disecadas, esquematizadas y fotografiadas, se registró la longitud del ducto hepático común y cístico con un caliper digital. La longitud promedio del ducto hepático común fue de 21,76 \pm 9,51 mm, variando de 4,18 $\mathrm{mm}$ a 50,64 $\mathrm{mm}$; la longitud promedio del ducto cístico fue de $19,11 \pm 6,77 \mathrm{~mm}$, variando de 7,28 a $38,88 \mathrm{~mm}$. Se observaron variaciones en 3 muestras $(7,3 \%)$, en una de ellas, el ducto cístico se unió al ducto hepático izquierdo, en otra, el ducto cístico se unió al ducto hepático derecho y en la otra muestra, se presentó una confluencia triple de ductos hepáticos, dos derechos y uno izquierdo. Los resultados obtenidos son un aporte a la anatomía clínica y quirúrgica de la región.

PALABRAS CLAVE: Anatomía; Trígono hépato-cístico; Ducto hepático común; Ducto cístico; Colecistectomía.

\section{REFERENCES}

Benson, E. A. \& Page, R. E. A practical reappraisal of the anatomy of the extrahepatic bile ducts and arteries. Br. J. Surg., 63:85360, 1976.

Berci, G. Biliary duct anatomy and anomalies. The role of intraoperative cholangiography during laparoscopic cholecystectomy. Surg. Clin. North Am., 72:1069-75, 1992.

Bornman, P. C.; Kottler, R. E.; Terblanche, J.; Kingsnorth, A. N.; Krige J. E. J. \& Marks, I. N. Does low entry of cystic duct predispose to stones in the common bile duct? Br. Med., 297:31$2,1988$.

Brandt, C. P. \& Eckhauser, M. L. Rare bile duct anomalies: a case report and implications for laparoscopic cholecystectomy. Surg. Endosc., 8:329-31, 1994.

Caroli-Bosc, F. X.; Demarquay, J. F.; Conio, M.; Deveau, C.; Hastier, P. \& Harris, A. Is biliary lithogenesis affected by length and implantation of cystic duct? Study of 270 patients with endoscopic retrograde cholangiopancreatography. Dig. Dis. Sci., 42(10):2045-51, 1997.

Cavalcanti, J. S.; Oliveira, E. D.; Santos, L. P.; Godoi, E. T.; Oliveira, C. L. \& Lins, A. P. Estudo anatomotopográfico das vias biliares extra-hepáticas e do trígono cisto-hepático. Acta Cir. Bras., 17(1):1-8, 2002.

Dohke, M.; Watanabe, Y. \& Okumura, A. Anomalies and anatomic variants of the biliary tree revealed by MR cholangiopancreatography. ARJ, 173:1251-4, 1999.

Foster, J. H. \& Wayson, E. E. Surgical significance of aberrant bile ducts. Am. J. Surg., 104:14-19, 1962.

Fujita, N.; Shirai, Y.; Ohtani, T. Junction of the cystic duct with the left hepatic duct: report of a case discovered during laparoscopic cholecystectomy. Surg. Laparosc. Endosc., 6:4457, 1996.

Gibney, R. G.; Nichols, D. M.; Osbone, J. C.; Fache, J. S.; Burhenne, H. J. Interhepatic duct: a new biliary anomaly. Gastrointest. Radiol., 12:134-6, 1987.

Kwon, A. H.; Uetsuji, S.; Ogura, T.; Kamiyama, Y. Spiral computed tomography scanning after intravenous infusion cholangiography for biliary duct anomalies. Am. J. Surg., 174:396-401, 1997.

Lamah, M.; Karanjia, N. D.; Dickson, G. H. Anatomical variations of the extrahepatic biliary tree: review of the world literature. Clin. Anat., 14:167-72, 2001.

Mortelem, K. J. \& Ros, P. R. Anatomic variants of the biliary tree: MR cholangiographic findings and clinical applications. AJR, 177:389-94, 2001.

Taourel, P.; Bret, P. M.; Reinhold, C.; Barkun, A. N.; Atri, M. Anatomic variants of the biliary tree: diagnosis with MR cholangiopancreatographhy. Radiology, 199:521-7, 1996.

Turner, M. A. \& Fulcher, A. S. The cystic duct: normal anatomy and disease processes. Radiographics, 21:3-22, 2001.

Uetsuji, S.; Okuda, Y.; Komada, H.; Yamamura, M.; Kamiyama, Y. Clinical evaluation of a low junction of the cystic duct. Scand. J. Gatroenterol ., 28:85-8, 1993.

Yamakawa, T.; Zhang, T.; Midorikawa, Y.; Ishiyama, J.; Takahashi, K.; Sugiyama, Y. A case of cystic duct drainage into the left intrahepatic duct and the importance of laparoscopic fundusfirst cholecystectomy for prevention of bile duct injury. $J$. Laparoendo. Adv. Surg. Tech., 17(5):662-5, 2007.

\section{Correspondence to:}

Prof. Carla Gabrielli

Depto. Ciências Morfológicas - Centro de Ciências Biológicas - Universidade Federal de Santa Catarina - Campus Universitário Trindade - Florianópolis - SC -

CEP 88040-900

BRASIL

E-mail: carla.gabrielli@ufsc.br

Received: 11-08-2011

Accepted: 21-11-2011 